\title{
Economic evaluation of the use of exogenous pulmonary surfactants in preterm newborns in a Mexican population
}

\author{
Guillermo Salinas-Escudero, MSc,, ${ }^{(1)}$ Alfonso Reyes-López, MSc,(2) Juan Garduño-Espinosa, MD, MSc,, \\ Miguel Angel Villasís-Keever, MD, MSc, ${ }^{(3)}$ Silvia Martínez-Valverde, MSc, (1) Onofre Muñoz-Hernández, MD, MSc. ${ }^{(2)}$
}

\begin{abstract}
Salinas-Escudero G, Reyes-López A, Garduño-Espinosa J, Villasís-Keever MA, Martínez-Valverde S, Muñoz-Hernández 0. Economic evaluation of the use of exogenous pulmonary surfactants in preterm newborns in a Mexican population. Salud Publica Mex 20 12;54 suppl I:S73-S8I.
\end{abstract}

\begin{abstract}
Objective. To estimate the cost-effectiveness ratio of surfactant rescue treatment of premature infants with respiratory distress syndrome (RDS) who are covered by the Medical Insurance for a New Generation. Materials and Methods. A cost-effectiveness evaluation was conducted from the thirdpayer perspective. Comparisons were made between the use of bovine surfactant (BS) therapy and without BS therapy. A decision tree model with a lifetime horizon was used where the measurements of effectiveness were life years gained (LYG) and quality-adjusted life years (QALYs). A $5 \%$ discount rate was considered for costs and health outcomes. All costs are expressed in Mexican pesos 2009. Results. Incremental cost-effectiveness ratios (ICER) were MXN\$136 670 per LYG and MXN\$I 25250 per QALY. Conclusion. Surfactant therapy was confirmed as a cost-effective strategy in accordance with World Health Organization criteria of three per capita gross domestic product (GDP) per QALY in premature infants with RDS in Mexico.
\end{abstract}

Key words: cost effectiveness; surfactant; respiratory distress syndrome; direct medical costs; life years gained; quality adjusted life years; Mexico
Salinas-Escudero G, Reyes-López A, Garduño-Espinosa J, Villasís-Keever MA, Martínez-Valverde S, Muñoz-Hernández 0. Evaluación económica de la utilización de surfactantes pulmonares exógenos en recién nacidos pretérmino en población mexicana.

Salud Publica Mex 2012;54 supl I:S73-S8I.

\section{Resumen}

Objetivo. Estimar la razón de costo efectividad incremental del tratamiento de surfactante de rescate en pacientes pretérmino con Síndrome de Dificultad Respiratoria (SDR) cubiertos por el Seguro Médico para una Nueva Generación. Material y métodos. Evaluación de costo-efectividad desde la perspectiva del tercer pagador. Los comparadores fueron la terapia de surfactante bovino y la alternativa de no emplear ésta. Se utilizó un árbol de decisión que consideró la esperanza de vida como horizonte temporal y las medidas de efectividad fueron los años de vida ganados (AVG) y los años de vida ajustados por calidad de vida ( AVAC). Resultados en pesos mexicanos del 2009. Resultados. Las RCEl por AVG y AVAC fueron de MXN\$I36 670 y MXN\$I 25 250. Conclusión. La razón de costo por AVG y AVAC para la terapia de surfactantes en pacientes prematuros con SDR en México fue menor a tres veces el PIB per cápita, por lo que es una estrategia costo-efectiva según los criterios de la OMS.

Palabras clave: costo-efectividad; surfactante; síndrome de dificultad respiratoria; costos médicos directos; años de vida ganados; años de vida ajustados por calidad; México

(I) Centro de Estudios Económicos y Sociales en Salud, Hospital Infantil de México Federico Gómez. México DF, México.

(2) Dirección de Investigación, Hospital Infantil de México Federico Gómez. México DF, México.

(3) Unidad de Investigación en Epidemiología Clínica, Hospital de Pediatría, Centro Médico Nacional Siglo XXI. Instituto Mexicano del Seguro Social. México DF, México.

Received on: February 10, 2011 - Accepted on: September 8, 2011

Correspondence author: Mtra. Silvia Martínez Valverde, Hospital Infantil de México Federico Gómez. Dr. Márquez 162 , Edificio Mundet $2^{\circ}$ piso Col. Doctores. 06720 México DF, México. E-mail: smartinez@himfg.edu.mx 
$\mathrm{R}$ espiratory distress syndrome (RDS) in the newborn is defined as respiratory distress secondary to the inability of the type II pneumocyte to synthesize surfactant, causing a drop in pulmonary volume and progressive alveolar collapse. In the general population, the estimated incidence of premature births is $\sim 6$ to $10 \%{ }^{1}$ After 28 weeks of gestation (wGA), prenatal and neonatal mortality rates are closely tied to prematurity; ${ }^{2}$ neonatal mortality accounts for $40 \%$ of deaths in children $<5$ years old. ${ }^{3}$ RDS usually occurs in premature newborns. Its incidence is invers proportional to gestational age and birth weight; thus, during gestational ages $<30$ weeks, the incidence is $\sim 60 \%$, between 32 and 36 wGA the incidence is $15-20 \%$ and after 37 wGA is 5 percent. ${ }^{4}$

Some of the most widely known risk factors for RDS are preterm birth, male gender, Caucasian race, maternal diabetes, perinatal asphyxia, hypothermia, multiple pregnancy ${ }^{5-6}$ and caesarean birth.

Cochrane's 2001 review indicates that for each 100 children treated prophylactically, two cases of pneumothorax and five deaths were prevented. However, prophylactic use of surfactant in fetuses $<32$ wGA represented treating twice as many infants as using the surfactant as rescue treatment. ${ }^{2}$ International studies have reported that surfactant rescue treatment in patients with RDS is a cost-effective and cost-saving procedure. ${ }^{7-11}$

On December 1, 2006, the Mexican Ministry of Health (SSA) launched the program Medical Insurance for a New Generation (Seguro Médico para una Nueva Generación, SMNG), which offers free medical coverage for children who do not have social security insurance. RDS is one of the diseases covered by the SMNG. In 2008, a total of 2485 RDS cases were covered by SMNG, and the amount currently established by the National Commission for Social Protection in Healthcare for payment per event of RDS covered is MXN\$40 194, representing approximately a total of MXN\$99 882090 for one year.

In this context, the SMNG makes a considerable investment in providing coverage for care of newborns with RDS, even though there is an international controversy regarding the effectiveness of surfactant therapies. For this reason, this study was planned to determine the cost-effectiveness ratios of rescue therapy with bovine surfactant (BS) in RDS patients and to establish if healthcare institution costs are justified.

The main objective of this study was to generate information about the incremental cost-effectiveness ratio for rescue treatment using $\mathrm{BS}$ vs. the alternative of no surfactant for management of RDS in premature newborns.

\section{Materials and methods}

\section{Selection and justification of comparison treatments}

The comparison treatments included in the study were BS therapy vs. the alternative of not using BS. BS was included because it is the only treatment approved in protocols included in the SMNG. The perspective of the study was from the third payer, which in this case is the Mexican Ministry of Health (SSA).

A complete cost-effectiveness economic evaluation was carried out. Accordingly, the main result expressed the incremental cost-effectiveness ratio (ICER). The ICER seeks to determine whether one treatment is more cost-effective than another [i.e., when incrementally comparing a treatment with its respective comparison, we obtain a negative ratio (absolute dominance) and/ or the additional cost per additional unit of success is not reasonably high]. ${ }^{12,13}$

\section{Time horizon}

The time horizon was "lifetime" because our goal was to determine the long-term impact of the disease considering two stages. The first stage considered was the patient's first hospitalization, which lasted an average of 40 days. At this stage, the costs of hospitalization (during which time the patients receive the surfactant) and the probabilities of survival are evaluated (Figure 1).

The second stage considers the probability and the costs associated with patients who experienced complications related to RDS and who required intra-hospital or ambulatory care during the two years following their first discharge from the hospital. Those patients who survived during the first two years would then have a normal life expectancy.

\section{Review of evidence for the identification of health for modeling}

A systematic review of the literature was conducted, which identified the outcome measures used in the model including clinical effectiveness measures related to the utilization of evaluated comparisons as rescue therapy for infants with RDS. ${ }^{4-15,18}$

\section{Resource usage pattern}

Information regarding the resource usage pattern was obtained by means of two instruments, which were 


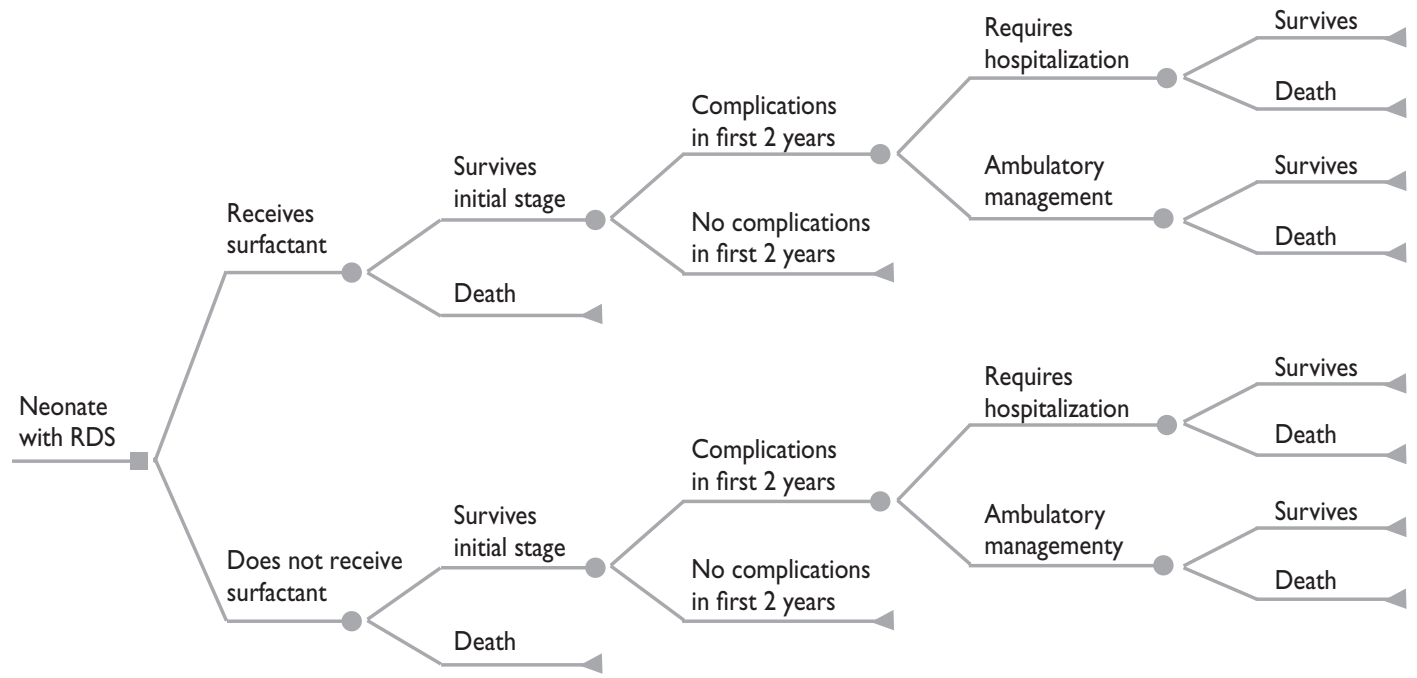

Figure I. Decision Tree Model for rescue use of surfactants. Mexico 2009

especially designed to obtain detailed patients' clinical information and the resources used during the entire process of patient care, available in the clinical records as well. One of these instruments contained the data from each patient's first hospitalization when RDS was diagnosed through the time the patient was discharged or died. During this period, patients who received surfactant were identified as cases and patients who did not receive surfactant as controls. The second instrument was designed to collect data regarding hospital care when patients needed re-hospitalization due to RDS complications.

\section{Review of clinical records}

A review of clinical records was conducted in two hospitals where the SMNG authorized transfers for catastrophic expenses related to RDS in 2008. The selection process for the reviewed clinical files was based on a sampling by quotas and was defined by population screening criteria.

\section{Criteria for selection of clinical records (cases)}

1. Neonates with RDS who were treated with BS

2. Complications of RDS after medical discharge from the hospital

\section{Criteria for selection of clinical records (controls)}

1. Neonates with RDS who were not treated with surfactant

2. Complications of RDS after medical discharge from the hospital

A total of 76 clinical charts of patients with RDS were reviewed from Hospital General de México and Hospital Infantil de México Federico Gomez.

\section{Costs}

Due to the perspective of the evaluation, only direct medical costs for healthcare incurred in managing such patients were included, using the case-mix technique.

The model considered the total cost of medical care from the initial hospitalization (45 days) and management of RDS-related complications (2 years), which were comprised of days spent in the neonatal intensive care unit (NICU), days of hospitalization with incubator, laboratory studies, medications, specialist consultations, days on ventilator, days with parenteral nutrition, days with oxygenation, surgical procedures, and re-hospitalizations. The cost was identified according to whether or not the patient received surfactant. Finally, the median of costs and the interquartile range (IQR) were reported 
for the model. Data were analyzed with Excel, SPSS v.16 (Chicago, IL) and Tree Age (2009) software.

\section{Sources of information on costs}

Information on costs for medical care was obtained from charge lists from the Hospital Infantil de México Federico Gomez during 2008. Such charges are not considered as a government subsidy. Unit prices of medications and medical material were obtained from lists of drugs purchased from the hospital in 2008. Cost information was updated for inflation and reflected increases for 2009 prices.

\section{Economic model}

The tool used to develop the economic model was a decision tree for lifetime horizon which, in ac- cordance with the recommendations of the General Counsel on Health for preparation of Guidelines on Healthcare Economics and Pharmaco-economics, ${ }^{16}$ included a 5\% discount rate on costs and on health outcomes.

\section{Model of rescue use of surfactants}

As a measurement of effectiveness in the model, two outcomes were used: life years gained (LYG) and quality-adjusted life years (QALYs). In the LYG model, the annual values used for surviving patients were 1 (Table I).

In the case of patients who died, we considered an adjustment for the middle period of the year according to the average time in each phase in which death would occur; therefore, the value for patients who died during the first 45 days (first hospitalization) was 0.062

Table I

Parameters and assumptions in the model by treatment arm. Mexico 2009

\begin{tabular}{lccc} 
Health outcomes & Case & Control & Source [Ref.] \\
Mortality (45 days) & $15.8 \%$ & $22 \%$ & $\mathrm{Cl}(10-30)$ \\
\hline Mortality (2 year follow-up of infants treated for neonatal RDS) & $\mathrm{Cl}(13.3-17.64)$ & $30.5 \%$ & {$[14,15]$} \\
\hline Complications (2 years*) & $21.9 \%$ & $\mathrm{Cl}(18.6-25.3)$ & $\mathrm{Cl}(26.8-34.2)$ \\
\hline Re-hospitalization due to complications (to 2 years) & $45.5 \%$ & $50 \%$ & {$[18]$} \\
\hline
\end{tabular}

Effectiveness measurements

\begin{tabular}{|c|c|c|}
\hline Utility value associated without complications & I & \\
\hline Utility value associated with complications & 0.87 & [17] \\
\hline Life expectancy for survivors (years) & 75.84 & [19] \\
\hline Life expectancy for infants who died during the first 45 days ( ${ }^{\text {st }}$ hospitalization) (years) & 0.616 & $\ddagger$ \\
\hline Life expectancy for infants who died during the 2 years (years) & 1.0616 & $\ddagger$ \\
\hline Discounted rate (\%) & $\begin{array}{c}5 \\
(3-8)\end{array}$ & [16] \\
\hline
\end{tabular}

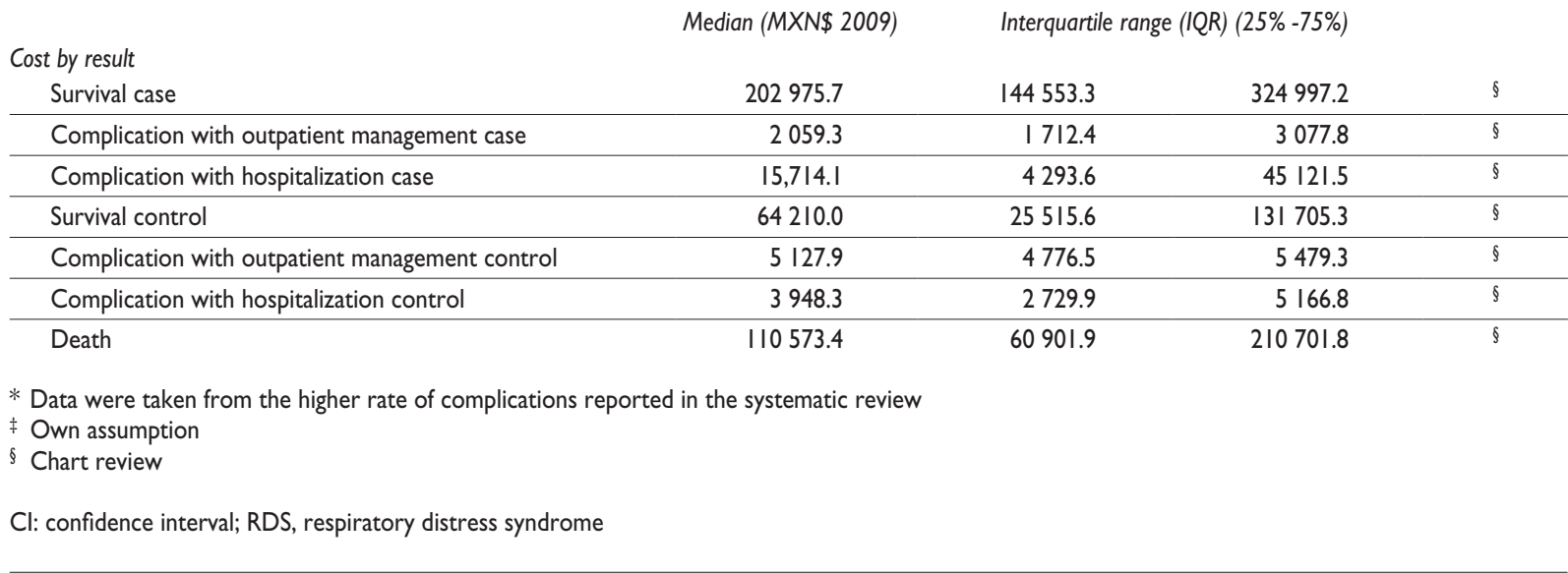


considering 22.5 days of life and 1.062 if the patient died during the half-period of the two years.

In the QALY model, the utility values used were 1 and 0.87 for patients without and with complications, respectively, adjusted by life time. Quality of life values for such patients are obtained from the study by Lorch et al. ${ }^{17}$

The life expectancy used for survivors was 75.84 years, which corresponds to the values reported for Mexico and based on the number of births according to gender in 2009. ${ }^{19-20}$ Finally, the LYG and QALYs were brought up to present values with a $5 \%$ discount rate, which was applied to both (costs and health outcomes).

\section{Sensitivity analysis}

A univariate analysis of probabilities of survival and costs was conducted. Distributions are reported in Table I. Probabilistic analysis was then conducted by second-order Monte Carlo simulation using beta distributions for probabilities, gamma for costs, and triangular for utilities.

\section{Results}

\section{Cost-effectiveness results}

In the base case (deterministic model), average costs for the groups with and without surfactant are MXN\$190 285 and MXN\$76 285, respectively. The effectiveness obtained was 10.93 and 10.09 LYG for the groups with and without surfactant and 10.74 and 9.83 QALYs, respectively. Finally, the costs per additional LYG and QALY with the use of surfactant are MXN\$136 670 and MXN\$125 250, respectively.

In addition, a subanalysis was developed for the group of 28 to $32 \mathrm{wGA}$, with the hypothesis that surfactant may have better effectiveness in this group, using the same effects and adjusting the cost according to age group. Costs were MXN\$168 566 and MXN\$70 598 for surfactant and without surfactant, respectively, and the ICERs were MXN\$116 422 per LYG and MXN\$107 657 per QALY.

As shown in both estimations, higher costs are incurred with the use of surfactant, but the obtained LYG and QALYs equally increase. The results obtained in the subanalysis for the group of 28 to $32 \mathrm{wGA}$ support the hypothesis in this group regarding improvement of the ICER.

\section{Results of the univariate sensitivity analysis}

The results of the univariate analysis are shown in a summarized form with the use of a tornado diagram (Figure 2). The probability of survival of neonates who do not use surfactant in the first 45 days increases to 0.78 , and the incremental cost-effectiveness ratio of surfactant use is dominated in both models (LYG and QALY).

Another important factor in the LYG was the cost of control survival. If we increase this cost to MXN\$131 705, the ICER increases to MXN\$280 279. On the other hand, if we reduce the probability of survival control complications to 0.532 , then the ICER increases to MXN\$191 188.

\section{Results of the probabilistic sensitivity analysis}

A less arbitrary approach for assessing the model sustainability is using the Monte Carlo simulation (stochastic sensitivity analysis) that also incorporates all parameter uncertainties. This method consists basically of calculating the ICER iteratively, using random values of known distributions, which assigns greater weight to the possible value combinations of the parameters.

Figure 3 shows the distribution of ICERs after running 10000 iterations in the simulation. A horizontal line was drawn over the dispersion charts at the level of MXN\$327 666 because that value can be used as a cost-effectiveness threshold for Mexico. This level was based on the WHO recommendation to use per capita GDP multiplied by three as a cost-effectiveness threshold for medium-income countries such as Mexico.

These stochastic results on the level of cost-effectiveness clearly allow us to assess the robustness of the model. The ellipse on joint density of incremental costeffectiveness allows us to conclude that these results have a normal multivariate distribution.

Finally, the acceptability curves allows us to determine if the use of surfactant is cost-effective as the cost-effectiveness threshold varies, which can be used as a decision-making rule based on decision makers' availability to pay. Figure 4 demonstrates how by utilizing the proposed threshold of the $\mathrm{WHO}^{21}$ of USD $\$ 25243^{22,23}$ (exchange rate $1 \mathrm{USD}=12.98 \mathrm{MXN}$ ), ${ }^{24}$ equivalent to MXN\$327 666 per LYG and QALY, the use of surfactant is almost $76 \%-79.1 \%$ cost-effective, respectively, compared with the alternative of not using surfactant for treatment of RDS in preterm newborns. 


\section{LYG}

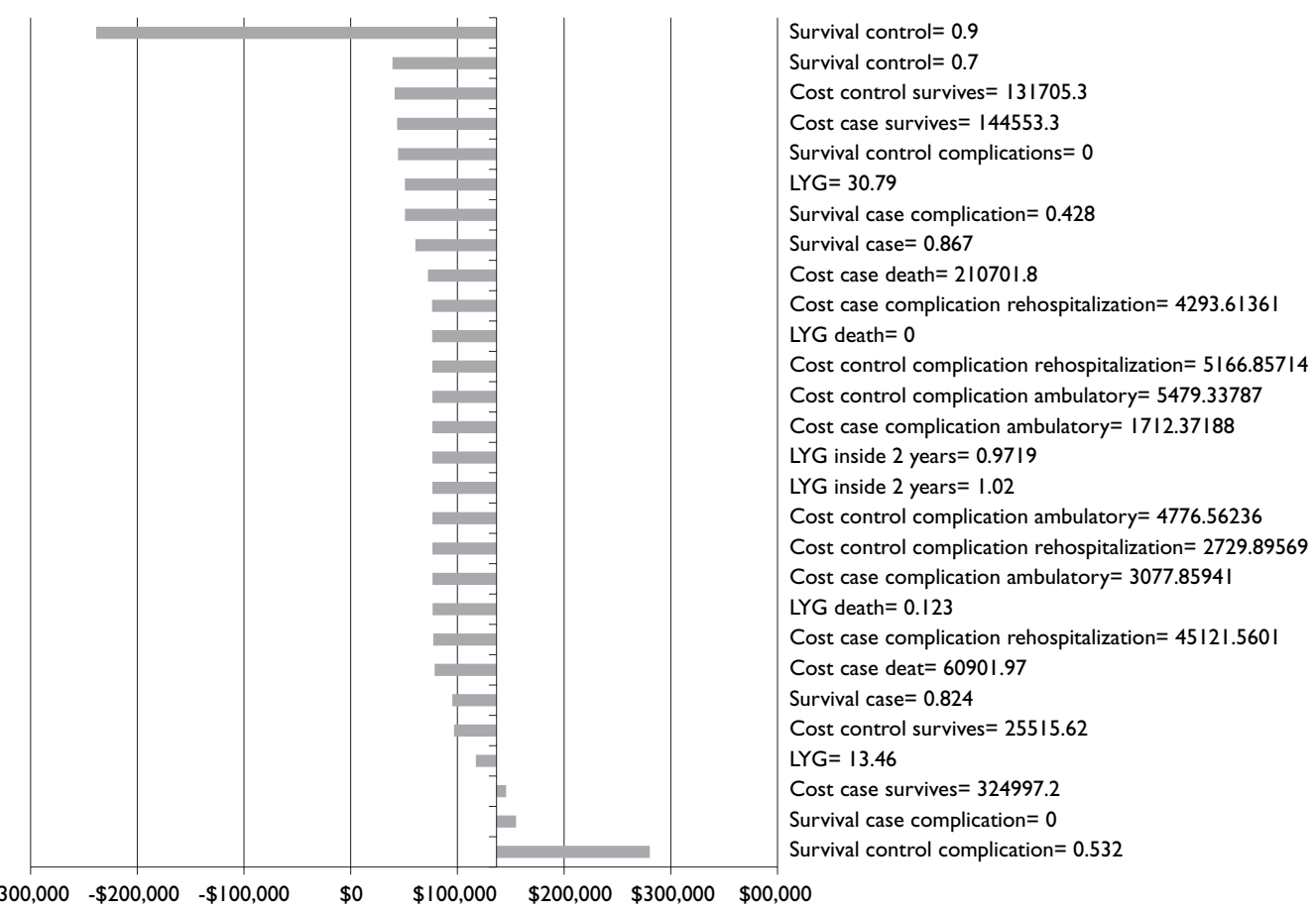

\section{QALY}

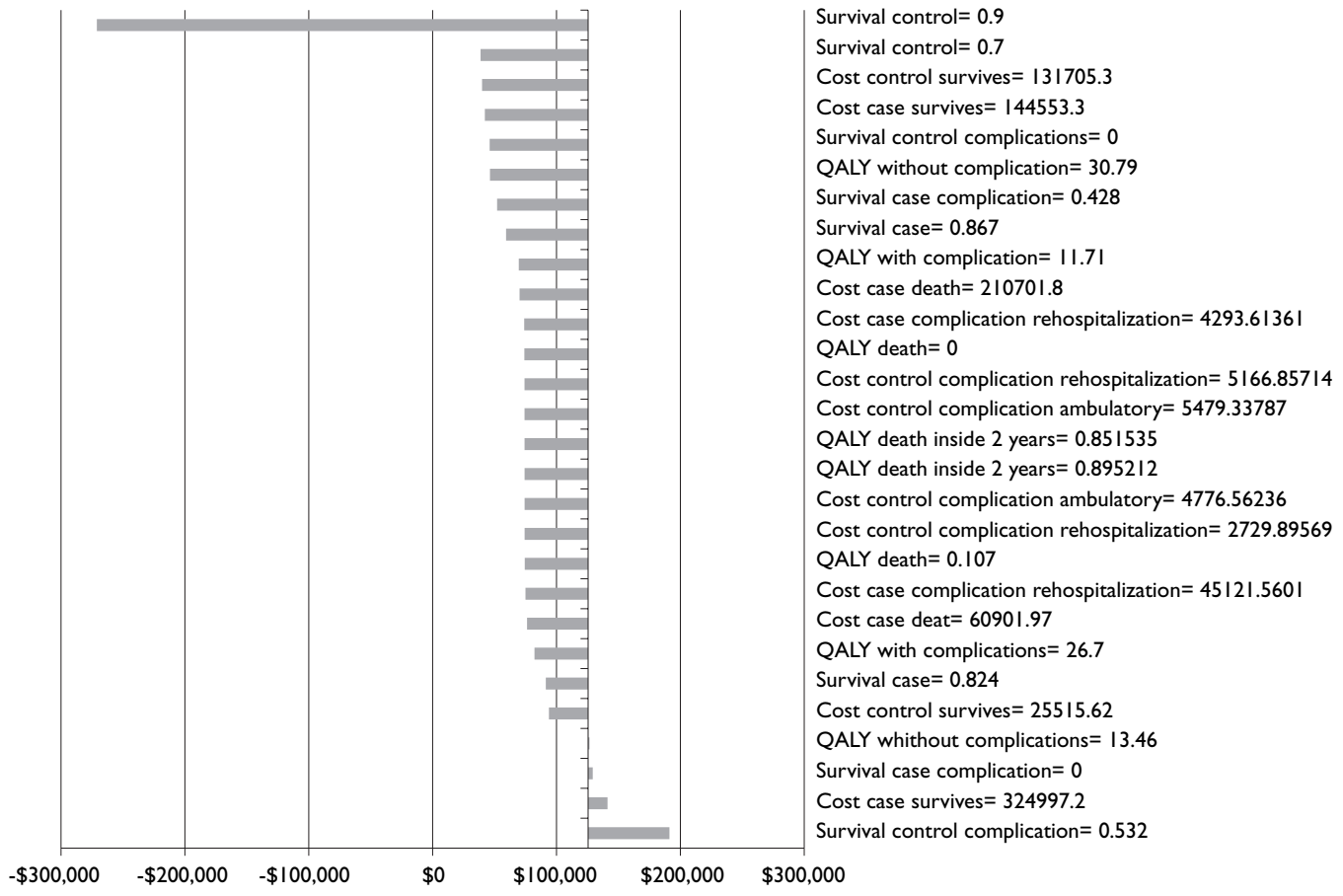

Figure 2. Tornado diagram 

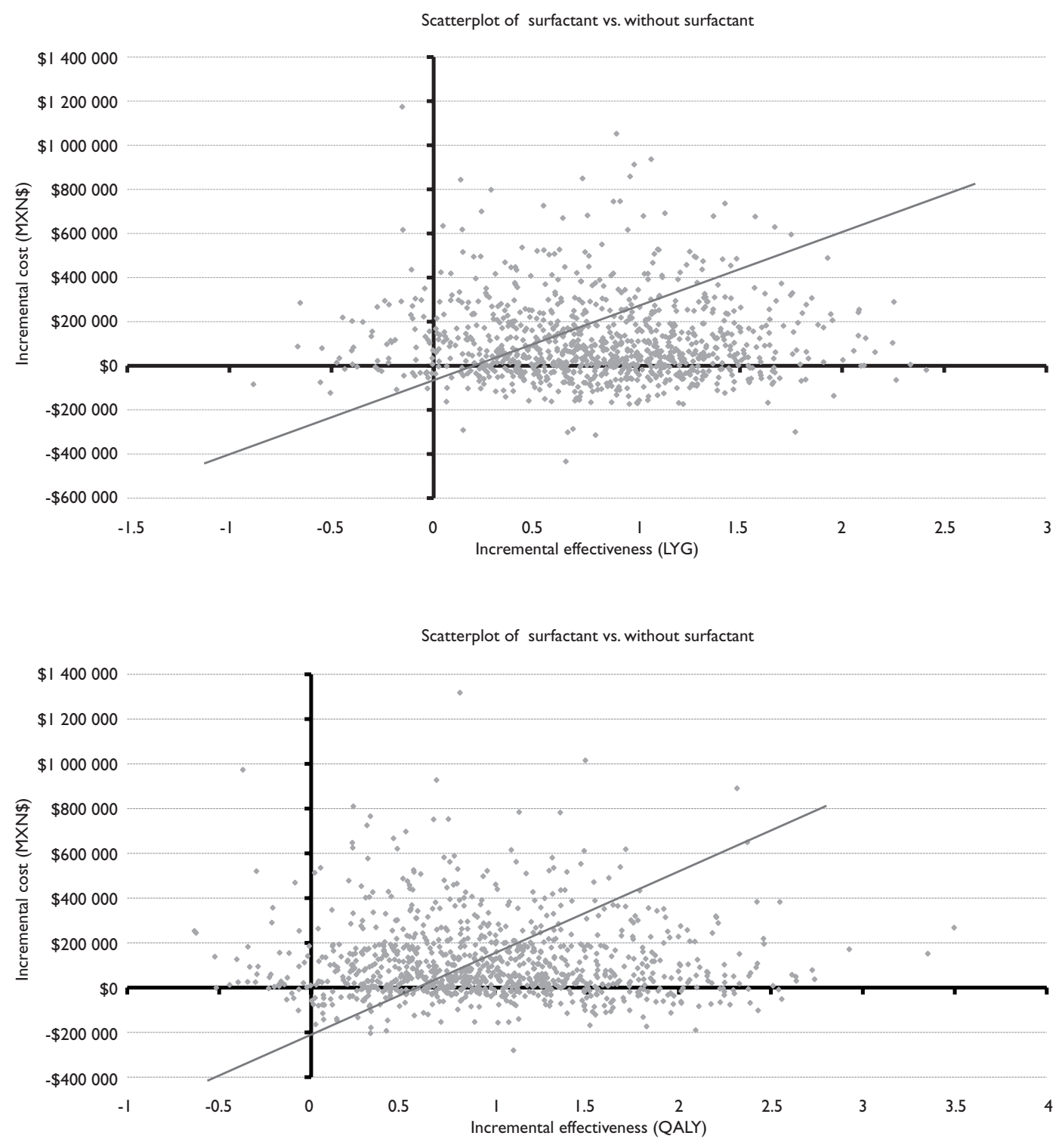

\section{Figure 3. INCREMENTAL COST EFFECTIVENESS PLANES}

On the other hand, the probability of cost-saving was $25.4 \%$ and $23.8 \%$, respectively.

\section{Discussion}

The results obtained in this study are consistent with economic publications on neonatal care and the policy of using surfactant. Several studies report that the use of surfactant in providing care for RDS patients is efficient in economic term $\mathrm{s}^{25}$ and is one of the safest approaches compared with other therapeutic interventions in premature neonates. ${ }^{7,26,27}$ In this context, it is important to mention that neonatal care has dramatically changed in recent decades; therefore, the current policy on the use of surfactant depends on of the availability of other therapies and technologies such as prenatal corticoids or other forms of mechanical ventilation.

For this reason, the results of this study may help decision-makers for funding and designing focalized programs to consider supplying surfactants in facilities 

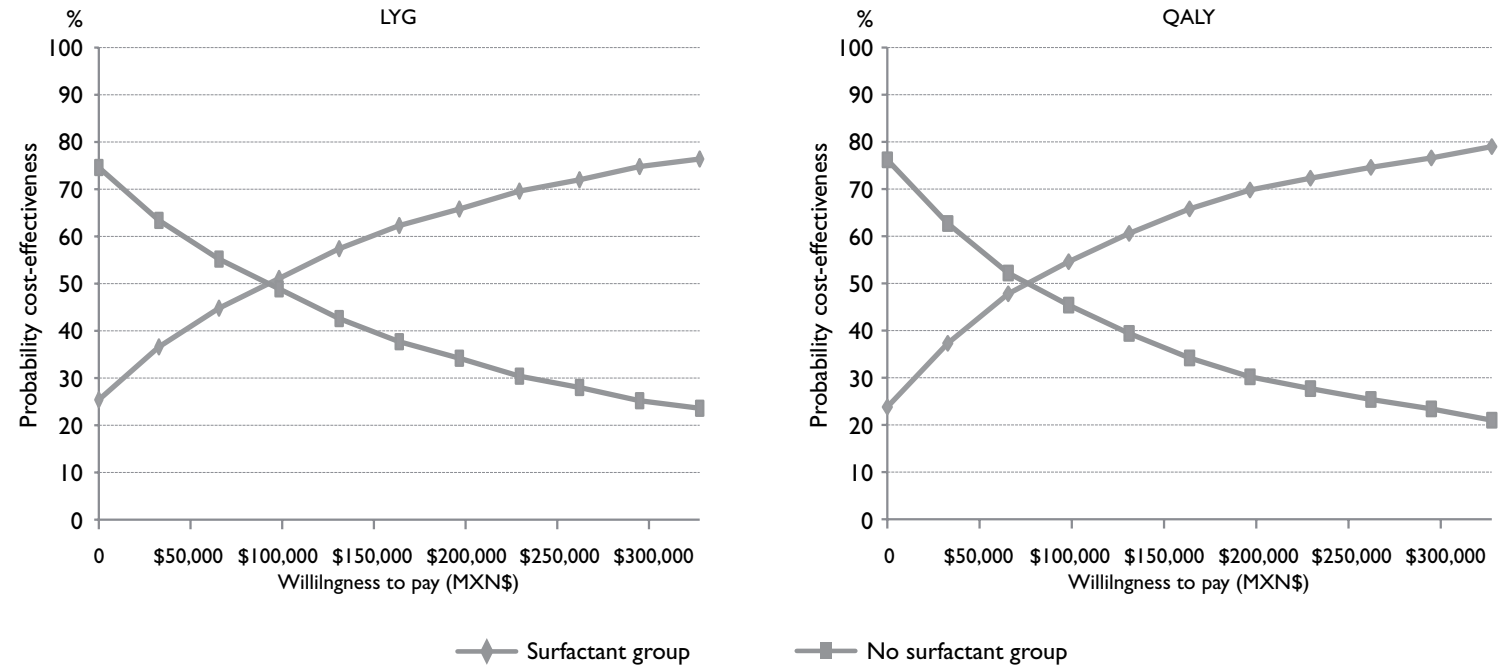

Figure 4. Acceptability curves

devoted to the care of premature infants as a key factor to diminish complications and to increase survival of RDS patients.

In relation to the considerations regarding the costeffectiveness of surfactant, it is necessary to define the potential willingness of the SMNG to pay for the use of effective technologies in the area of healthcare. In Mexico, there is no clear criterion regarding the budget threshold for determining cost-effective health interventions.

The results of this study show that the added cost per LYG is MXN\$136 670 and MXN\$125 250 per QALY, which represents a level of investment below the most conservative thresholds. This conclusion, however, required us to assume a lifespan for children who were rescued with the use of surfactant. In that case, we could undeniably consider the incremental cost-effectiveness of surfactant in treatment of RDS.

Additionally, we carried out an analysis for the 28$32 \mathrm{wGA}$ group and found ICERs were more cost effective (MXN\$116 422 per LYG and MXN\$107 657 per QALY) when compared with the base case, which included different gestational ages. Therefore, results show an improvement pattern for ICERs at least for this group (data not shown).

Because of the above, even when this second analysis reported ICERs for QALY and LYG, the PROFIT et al. ${ }^{25}$ study reported the same positive ratio for disabilityadjusted life years (DALYs) according to gestational age, even when the outcome from both studies cannot be compared.
Measurements of effectiveness used in this study (LYG and QALY) may be a subject of controversy; so far, there is a lack of information regarding long-term follow-up of RDS survivors who were treated with surfactants.

Results of the sensitivity analysis showed that only changes in the probability of survival in the control group have a potential impact on the ICER by LYG and QALY. In other words, the major impact on parameters improves the base case results; therefore, we may consider that the model estimations are robust and consistent.

Estimated costs of medical care for an episode of RDS that used surfactant in our study were higher than treating an episode without surfactant. This may be justified because as survival of premature patients increases, they consume more resources and, consequently, neonatal care costs are increased..$^{26-28}$ In contrast, Pjaver et al. in Saudi Arabia ${ }^{10}$ reported an incremental savings of USD\$12 283 in a group of patients treated with surfactant. This discrepancy may be attributed to the cost structures for hospitalization, which differ from ours.

Umrab et al. ${ }^{11}$ also found that the use of surfactant is a cost-saving strategy (USD $\$ 11890$ per patient) because number of hospitalization days was lower in the surfactant group than days reported in the group not using surfactants.

This study has some limitations. First, patterns of care were apparently different between cases and controls. We had more controls in one of the two hospitals surveyed in which a less resource-intensive care pattern 
was observed. This trend appears based on patterns of medical practice and resource limitations.

Another limitation involves the precision of estimated costs because a relatively small sample size regarding complications follows in time. A third limitation is related to the representativeness of the included patients. Due to feasibility, only two hospitals were surveyed; therefore, neonatal practices may be different in other hospitals. It is expected that costs change with greater degrees of variation.

In conclusion, surfactant therapy in premature newborns with RDS is a cost-effective strategy in accordance with the criteria of the WHO, using three GDP per capita per QALY in Mexico.

Declaration of conflict of interests: The authors declare that they have no conflict of interests.

\section{References}

I. Goldenberg RL, Culhane JF, lams JD, Romero R. Epidemiology and causes of preterm birth. Lancet 2008; 37I(9606):75-84.

2. Yost CC, Soll RF. Early versus delayed selective surfactant treatment for neonatal respiratory distress syndrome. Cochrane Library Syst Rev 2000;(2):CD00I456.

3. Soll RF. Prophylactic natural surfactant extract for preventing morbidity and mortality in preterm infants. Cochrane Database Syst Rev 2000;(2):CD0005II.

4. López-Tajamana NL, Rodríguez-Zepeda J], Zavala-Mendoza A, Mendoza-Dominguez S, Torres-Pacheco $\mathrm{C}$. Administración de surfactante exógeno en el tratamiento del síndrome de dificultad respiratoria neonatal, en su modalidad de rescate. Rev Mex Pediatr 1999;66:5-8. 5. Pérez-Molina JJ, Blancas-Jacobo O, Ramírez-Valdivia JM. Enfermedad de membrana hialina: mortalidad y factores de riesgo maternos y neonatales. Ginecol Obstet Mex 2006;74:354-359.

6. Fraser J, Walls M, McGuire W. Respiratory complications of preterm birth. BMJ 2004:329(7472):962-965.

7. Tubman TR, Halliday HL, Normand C. Cost of surfactant replacement treatment for severe neonatal respiratory distress syndrome: a randomised controlled trial. BMJ 1990;30I(6756):842-845.

8. Victorian Infant Collaborative Study Group. Economic outcome for intensive care of infants of birthweight 500-999 $\mathrm{g}$ born in Victoria in the post surfactant era. J Pediatr Child Health 1997;33:202-208.

9. Phibbs CS, Phibbs RH, Wakeley A, Schlueter MA, Sniderman S, Tooley WH. Cost effects of surfactant therapy for neonatal respiratory distress syndrome. J Pediatr 1993;123:953-962.

10. Pejaver RK, al Hifzi I, Aldussari S. Surfactant replacement therapyeconomic impact. Indian J Pediatr 200I;68:50I-505.

I I. al Umran K, Yaseen H. Cost-effectiveness of surfactant replacement therapy in a developing country. J Trop Pediatr 1997;43:167-169.
12. Laupacis A, Feeny D, Detsky AS, Tugwell PX. How attractive does a new technology have to be to warrant adoption and utilization? Tentative guidelines for using clinical and economic evaluations. Can Med Assoc J |992;|46:473-48|.

13. Rawlins MD, Culyer AJ. National Institute for Clinical Excellence and its value judgments. BMJ 2004;329(7459):224-227. doi: I0. II 36.

14. Villasis KMA, Rendón MME, García JH, Escamilla NA, Salinas EG, Martínez VS, et al. Revisión sistemática y meta-análisis sobre la efectividad del surfactante bovino como tratamiento de prematuros con síndrome de dificultad respiratoria. Bol Med Hosp Infant Mex 2010;67:477-49I. 15. Seger N, Soll R. Animal derived surfactant extract for treatment of respiratory distress syndrome. Cochrane Database Syst Rev 2009;2:CD007836.

16. Secretaría de Salud. Consejo de Salubridad General. Guía para la conducción de estudios de evaluación económica para la actualización del Cuadro Básico de Insumos del Sector Salud en México. México: SSA, 2008. 17. Lorch SA, Cnaan A, Barnhart K. Cost-effectiveness of inhaled nitric oxide for the management of persistent pulmonary hypertension of the newborn. Pediatrics 2004; I 14:4 I7-426.

18. Two-year follow-up of infants treated for neonatal respiratory distress syndrome with bovine surfactant. Survanta Multidose Study Group. J Pediatr 1994;124:962-967.

19. Consejo Nacional de Población. Proyecciones de la Población en México 2005-2050.México. [Accessed 2009 May]. Available at: http:// $w w w$. conapo.gob.mx/index.php?option=com_content\&view=article\&id= 36\&ltemid $=234$

20. Secretaría de Salud. Dirección General de Información en Salud. Base de datos de nacidos vivos registrados 1990-2007. Sistema Nacional de Información en Salud (SINAIS). México. [Accessed 2009 April]. Available at: http://www.sinais.salud.gob.mx.

21. World Health Organization. The World Health Report 2000. Health Systems: Improving Performance. Geneva Switzerland. [Accessed 2009 October]. Available at: http://www.who.int/whr/2000/en/whr00_en.pdf 22. Instituto Nacional de Estadística y Geografía. Sistema de Cuentas Nacionales. Tercer Trimestre 2009. [Accessed 2009 November]. Available at: http://dgcnesyp.inegi.org.mx/cgi-win/bdiecoy. exe/572? s=est\&c $=12546$

23. Consejo Nacional de Población. Indicadores demográficos básicos 1990-2030. [Accessed 2009 June]. Available at: http://www.conapo.gob. $\mathrm{mx} /$ index.php?option $=$ com_content\&view $=$ article\&id $=|25 \&|$ temid $=193$ 24. Banco de México. Mercado cambiario. [Accessed 2009 November]. Available at: http://www.banxico.org.mx/portal-mercado-cambiario/ index.html

25. Profit J, Lee D, Zupancic JA, Papile L, Gutierrez C, Goldie SJ, et al. Clinical benefits, costs, and cost-effectiveness of neonatal intensive care in Mexico. PLoS Med 2010;7:el000379. doi:10.137I/journal.pmed. 1000379.

26. Mugford M, Howard S. Cost effectiveness of surfactant replacement in preterm babies. Pharmacoeconomics 1993;3:362-373.

27. Ainsworth SB, Milligan DW. Surfactant therapy for respiratory distress syndrome in premature neonates: a comparative review. Am J Respiratory Med 2002;।:4|7-433.

28. Mugford M. Cost effectiveness of prevention and treatment of neonatal respiratory distress (RDS) with exogenous surfactant: what has changed in the last three decades? Early Hum Dev 2006;82: 105-II5. 